\title{
Perspektif Tuhan atau manusia? Pengaruh sudut pandang terhadap penilaian bias dalam kelompok
}

\author{
Okky Arif Rachmanputra* \& Mirra Noor Milla \\ Fakultas Psikologi, Universitas Indonesia, Depok
}

\begin{abstract}
Abstrak
Penelitian ini bertujuan untuk melihat pengaruh sudut pandang terhadap pemikiran bias dalam kelompok agama. Variabel sudut pandang terbagi atas dua variasi yaitu sudut pandang diri dan sudut pandang Ketuhanan. Penelitian ini ingin melihat apakah terdapat perbedaan antara individu yang mengaktifkan sudut pandang diri dengan sudut pandang Ketuhanan terhadap pemikiran bias dalam kelompok agama. Penelitian ini memiliki disain penelitian eksperimen. Partisipan penelitian ini adalah 81 mahasiswa dan beragama Islam. Partisipan secara acak dikelompokkan berdasarkan kondisi manipulasi penelitian, yaitu sudut pandang diri dan sudut pandang Ketuhanan. Partisipan diminta untuk menentukan apakah mereka bersedia memberikan donasi kepada panti asuhan yang merepresentasikan umat Muslim atau panti asuhan yang merepresenatsikan umat agama lain. Hasil penelitian menunjukkan bahwa tidak terdapat perbedaan pada kelompok partisipan yang mengaktifkan sudut pandang diri dengan sudut pandang Ketuhanan terhadap pemikiran bias dalam kelompok $\chi 2(2)=0,240, p=0,624>0,05$. Artinya, pada partisipan baik yang mengaktifkan sudut pandang diri maupun sudut pandang Ketuhanan, tetap memberikan donasi kepada panti asuhan yang merepresentasikan agamanya dan umat agama lain. Konteks dimana absennya keadaan konflik antar kelompok agama di Indonesia menjadi salah satu alasan yang dapat menjelaskan hasil penelitian ini.
\end{abstract}

Kata kunci: bias dalam kelompok, sudut pandang diri, sudut pandang ketuhanan, perilaku prososial, kelompok agama, hubungan antarkelompok

\begin{abstract}
This study aimed to examine the influence of the perspective-taking on ingroup bias in religious groups. The independent variable was divided into two variations, self-perspective and Godperspective. This research wanted to see whether there were differences between individuals who activate their self-perspective compared to God-perspective on ingroup bias in religious groups. We employed experimental research design, with 81 Muslim college students as participant. They were randomly grouped based on the two perspective, in a between-group design. Participants were asked to determine whether they will be willing to donate to an orphanage that represents Muslims or other religions. Using chi-square analysis, the results showed that there was no difference in the group of participants who activated their self-perspective and the God-perspective on ingroup bias $(\chi 2(2)=0.240, p=0.624>.05)$. This means that for participants on both conditions would still give donations to orphanages that represent their religion and the people from other religions. Contextual explanation where there is an absence of conflict between religious groups in Indonesia, was one reason that could explain the results.
\end{abstract}

Keywords: Ingroup bias, self-perspective, God-perspective, Prosocial Behavior, Religious Group, intergroup relations

\section{Pendahuluan}

Beberapa penelitian telah menjelaskan bahwa keanggotaan dalam kelompok agama dapat memicu pemikiran bias dalam kelompok agama (Ginges, Hansen \& Norenzayan, 2009; Johnson, Rowatt, \& LaBouff, 2010). Terjadi demikian, karena ketika individu memeluk agama tertentu, maka dirinya akan terafilisasi dengan kelompok agama dan memiliki identitas sosial sebagai anggota kelompok agama tersebut (Preston \& Ritter, 2013). Keanggotaan agama ini sejalan dengan teori identitas sosial oleh Tajfel (1970), dimana identitas sosial membuat individu mempersepsi sosok 'kita' pada kelompoknya atau dapat disebut sebagai kelompok ingroup dan sosok 'mereka' pada kelompok lain atau dapat disebut sebagai kelompok outgroup. Ketika individu memiliki identitas sosial, maka individu 
tersebut membentuk konsep diri baru yang berkaitan dengan kelompoknya. Hal ini menciptakan kondisi dimana keberhargaan diri individu dipenuhi oleh keberhargaan diri kelompok tersebut. Kemudian individu dapat memberi penilaian lebih positif kepada kelompoknya (ingroup) dan cenderung negatif kepada outgroup, dengan tujuan mempertahankan keberhargaan diri dan kelompoknya (Tajfel \& Turner, 1979).

Ginges dkk. (2009) melakukan penelitian bias antar kelompok agama pada konteks konflik Israel dan Palestina. Mereka menemukan bahwa seringnya seseorang pergi ke Sinagoge untuk mengikuti kegiatan kelompok agamanya, dapat memicu penilaian positif aksi bom bunuh diri oleh orang Yahudi terhadap kelompok Islam. Aksi bom bunuh diri dari seorang Yahudi bahkan dinilai positif sebagai aksi kepahlawanan bagi umat Yahudi yang sering melakukan kegiatan kelompok agamanya.

Bias dalam kelompok agama juga dapat terjadi ketika kelompok agama menilai kelompok etnis tertentu. Johnson dkk. (2010) menemukan bahwa orang yang memiliki tingkat religiusitas yang tinggi, akan cenderung lebih melakukan prasangka terhadap kelompok ras lain, yaitu etnis kulit hitam di Amerika. Bias tersebut terkait dengan konsep etik pada agama kristiani yang tidak sejalan dengan perilaku etnis kulit hitam yang dianggap sering mengalami kegagalan dalam pendidikan, pengangguran, dan tingkat kejahatan yang lebih tinggi dibandingkan kelompok etnis kulit putih di Amerika (Katz \& Hass, 1988).

Tingginya tingkat religiusitas seseorang berkaitan dengan bias dalam kelompok (LaBouff, Rowatt, Johnson, \& Finkle, 2012). Mereka berhasil menunjukkan bahwa individu yang memiliki religiusitas yang tinggi, lebih memberikan penilaian negatif kepada kelompok lain yang sebagian besar tidak berkaitan dengan agama, dibandingkan kelompok partisipan yang memiliki religiusitas rendah. Pemberian penilaian negatif tidak ditemukan kepada umat agama Kristen. Hal ini menunjukkan pada individu yang memiliki religiusitas tinggi dapat memiliki pemikiran bias dalam kelompoknya.

Mengapa pemikiran bias pada kelompok agama dapat terjadi sementara Tuhan di semua agama mengajarkan agar umatnya berperilaku baik, dalam arti menunjukkan perilaku prososial terhadap seluruh umat manusia (Preston, Ritter, \& Hernandez, 2010)? Inkonsistensi ini dijelaskan oleh Preston dan Ritter (2013) melalui dua konsep agama yaitu religion dan belief to God. Konsep religion adalah konsep berperilaku pada individu yang didasarkan pada sudut pandang agama, sebagai sebuah identitas kelompok sosial mencakup dimensi kelompok di dalamnya seperti tradisi, ritual, dan kegiatan-kegiatan agama serta norma sosial kelompok agamanya yang membedakannya dengan kelompok agama lain. Sedangkan belief to God dijelaskan oleh Preston dan Ritter (2013) adalah konsep berperilaku pada individu yang didasarkan pada sudut pandang agama, sebagai cara individu meyakini Tuhan yang adil dan memberikan rahmat kepada seluruh manusia tanpa membedakan agamanya. Individu dengan sudut pandang ini memiliki sudut pandang yang adil serta mengasihi individu lain tanpa melihat latar belakang kelompok agamanya. Konsep belief to God inilah yang menurut Preston dan Ritter (2013) diduga berperan menjelaskan individu yang tidak melakukan pemikiran bias dalam kelompok agama.

Ginges, Sheikh, Atran, dan Argo (2016), membahas bagaimana Belief to God atau sudut pandang Ketuhanan dapat mengurangi perilaku bias terhadap kelompok agama lain. Untuk itu, Ginges dkk. (2016) membedakan dua sudut pandang yang digunakan oleh individu terkait dengan Belief to God, yaitu sudut pandang diri dan sudut pandang Ketuhanan. Mereka menjelaskan bahwa sudut pandang self perspective adalah hasil persepsi individu terhadap konsep dirinya yang dapat berkaitan dengan identitas sosialnya sebagai umat atau anggota dari kelompok agama. Sedangkan sudut pandang God's perspective merupakan hasil persepsi individu terhadap ajaran Tuhan yang seharusnya dilakukan oleh setiap individu terhadap individu lain. Kedua sudut pandang ini dianggap dapat menentukan cara berpikir dan berperilaku pada individu terhadap individu lain. Ginges dkk. (2016) juga menjelaskan bahwa sudut pandang Ketuhanan berkaitan dengan konsep Tuhan yang adil dan tidak membedakan umat manusia. Hasil penelitian Ginges dkk. (2016) menunjukkan bahwa ketika seseorang mengaktifkan sudut pandang dirinya sendiri (self's perspective), ia akan lebih menyetujui untuk menolong anggota kelompok agamanya sendiri (individu beragama Islam dan berkewarganegaraan Palestina), dibandingkan anggota dari kelompok agama lain (individu beragama Yahudi dan berkewarganegaraan Israel). Akan tetapi, ketika partisipan mengaktifkan sudut pandang Ketuhanan (God's perspective), partisipan akan lebih menyetujui untuk menolong kedua korban, baik anggota kelompok agamanya (individu beragama Islam dan berkewarganegaraan Palestina) maupun anggota kelompok agama lain (individu beragama Yahudi dan berkewarganegaraan Israel). Hal ini menunjukkan bahwa ketika individu mengaktifkan sudut pandang Ketuhanan (God's perspective), perilaku bias terhadap kelompok agama lain tidak terjadi.

Preston dan Ritter (2013) juga menjelaskan bahwa sudut pandang Ketuhanan dapat memengaruhi intensi individu dari kelompok agama tertentu, untuk menolong kelompok agama yang berbeda. Penelitian Preston dan Ritter (2013) menggunakan dua variasi variabel independen berupa priming yang mengaktifkan identitas individu sebagai anggota kelompok agama dan priming yang mengaktifkan sudut pandang Ketuhanan, kemudian variabel dependen berupa intensi menolong kelompok agama lain. Priming tersebut dilakukan dengan memberikan pertanyaan tentang keyakinan (belief) partisipan tentang Tuhan. Pada kelompok partisipan yang diberikan priming identitas kelompok agama, jawaban pertanyaan tersebut bersifat terbuka. Sedangkan pada kelompok partisipan yang diberikan priming tentang sudut pandang Ketuhanan, jawaban pertanyaan 
tersebut bersifat tertutup (ya atau tidak). Penelitian Preston dan Ritter (2013) menemukan bahwa kelompok partisipan beragama Katolik yang diberikan priming sudut pandang Ketuhanan, memiliki intensi untuk memberikan donasi kepada kelompok ingroup dan outgroup. Artinya, partisipan yang mengaktifkan sudut pandang Ketuhanan cenderung tidak melakukan pemikiran bias dalam kelompok agamanya.

Di Indonesia, terdapat beberapa fenomena yang merepresentasikan pemikiran bias dalam kelompok agama. Seperti adanya penolakan siswa yang beragama non-Islam di daerah Banyuwangi (Stefanie, 2017) dan bias antar kelompok (Kanas, Scheepers, \& Sterkens, 2015) di kota Ambon (Maluku) antara kelompok umat Muslim dan Kristen. Adanya kasus pemikiran bias ini yang menjadi alasan peneliti untuk melakukan penelitian yang melihat bagaimana pengaruh sudut pandang pada individu terhadap pemikiran bias dalam kelompok agama. Lebih lanjut, peneliti menduga bahwa individu yang memiliki sudut pandang Ketuhanan akan cenderung tidak memiliki pemikiran bias dalam kelompok agamanya. Hal ini didasarkan pada Preston dan Ritter (2013) yang menjelaskan bahwa individu yang memiliki sudut pandang Ketuhanan menganggap bahwa setiap manusia adalah sesama makhluk Tuhan yang berhak mendapatkan hak untuk hidup dan kasih sayang dari Tuhan tanpa membeda-bedakan kelompok agama. Penelitian ini bertujuan untuk menjawab pertanyaan penelitian apakah individu yang menggunakan sudut pandang Ketuhanan memiliki pengaruh pada pemikiran bias terhadap kelompok agamanya atau ingroup bias.

Hipotesis yang diajukan dalam penelitian ini adalah terdapat perbedaan penilaian bias pada individu yang menggunakan dua sudut pandang diri dan Ketuhanan. Individu yang menggunakan sudut pandang Ketuhanan akan cenderung tidak menunjukkan perilaku bias pada kelompoknya, dibandingkan individu yang menggunakan sudut pandang dirinya sendiri.

\section{Metode Penelitian}

\section{Partisipan}

Pada eksperimen ini, sebanyak 81 mahasiswa, beragama Islam, pada rentang usia 18 sampai 26 tahun menjadi partisipan. 81 partisipan terbagi secara acak berdasarkan sudut pandang (Seniati, Yulianto, \& Setiadi, 2011). Sebanyak 20 partisipan adalah laki-laki $(24,7 \%)$ dan partisipan perempuan sejumlah 61 orang $(75,3 \%)$. Berdasarkan keikutsertaan dalam organisasi keagamaan, sebanyak 32 orang $(39,5 \%)$ partisipan ikut serta dalam organisasi keagamaan dan sebanyak 49 orang $(60,5 \%)$ partisipan tidak ikut serta dalam organisasi keagamaan.

\section{Desain}

Tipe penelitian ini adalah penelitian eksperimen. Dalam penelitian ini, peneliti akan memberikan manipulasi variabel independen. Desain pada studi ini adalah desain dua kelompok subjek atau between subject design. Variabel bebas yaitu sudut pandang dengan variasi yaitu sudut pandang berasal dari diri versus sudut pandang Ketuhanan. Serta variabel terikat yaitu bias dalam kelompok. Penelitian ini dilakukan untuk melihat pengaruh sudut pandang diri dan sudut pandang Ketuhanan terhadap bias individu terhadap kelompoknya.

\section{Prosedur}

Penelitian ini dilakukan pada bulan Februari hingga Maret 2019. Pelaksanaan penelitian dilakukan pada ruangan tertutup, yang di dalamnya terdapat meja dan kursi. Pada awal pelaksanaan penelitian, peneliti mempersiapkan lembar informed consent, stimulus penelitian (cover story dan priming) untuk variabel bebas, pertanyaan manipulation check, dan variabel terikat. Hal pertama yang dilakukan peneliti adalah membacakan instruksi penelitian. Peneliti menyamarkan tujuan penelitian dengan memberitahu partisipan bahwa penelitian akan berkaitan dengan kemampuan pengambilan keputusan. Kemudian peneliti mempersilakan partisipan untuk mengisi lembar informed consent yang berisikan nama, usia, agama, keikutsertaan pada organisasi keagamaan dan jenis kelamin. Peneliti juga mempersiapkan ruang kelas di Fakultas Psikologi Universitas Indonesia sebagai ruangan penelitian.

Kedua, peneliti membagi sesi penelitian menjadi dua bagian. Sebanyak 81 partisipan dibagi secara random ke dalam dua kelompok berdasarkan variabel sudut pandang. Kelompok sudut pandang diri sebanyak 40 partisipan dan sudut pandang Ketuhanan sebanyak 41 partisipan. Untuk kelompok sudut pandang Ketuhanan, partisipan akan diberikan ayat suci Al Quran yang membahas tentang berlaku adil terhadap sesama manusia, yaitu terjemahan Al Quran dari surat Al-Maidah ayat 8, yang menjelaskan bahwa setiap umat Islam hendak berperilaku adil terhadap semua manusia. Sedangkan kelompok sudut pandang diri tidak diberikan stimulus. Untuk manipulation check, kelompok sudut pandang Ketuhanan akan diminta me-rating pernyataan terkait pemahaman konsep Tuhan yang adil terhadap sesama manusia.

Peneliti memberikan pernyataan "Tuhan memberikan kasih sayangnya pada seluruh umat manusia" dan "Saya percaya Tuhan memerintahkan sesama manusia untuk berlaku adil". Partisipan akan menjawab dengan me-rating sangat tidak setuju (1) sampai dengan sangat setuju (7). Tingginya rating partisipan pada kedua pernyataan tersebut dibandingkan kelompok yang tidak diberikan sudut pandang Ketuhanan, maka manipulasi dapat disimpulkan berhasil.

Setelah itu, partisipan membaca skenario tentang bias pada kelompok. Skenario menceritakan tentang seorang remaja yang sedang meminta bantuan donasi untuk panti asuhan. Peneliti membuat dua skenario. Partisipan akan ditanyakan kesediaannya untuk memberikan donasi kepada 
panti asuhan bernama Kasih Kudus (representasi agama non-Islam) dan kemudian untuk panti asuhan bernama Radhatul Jannah (representasi agama Islam). Selain itu, partisipan juga diberikan tiga pertanyaan yang berkaitan dengan jalannya cerita skenario sebagai manipulation check. Pertanyaan untuk manipulation check menanyakan apa yang dilakukan oleh tokoh remaja dalam skenario, nama dari Panti Asuhan, dan tujuan dari donasi yang akan disumbangkan. Partisipan akan menjawab ketiga pertanyaan tersebut dengan memilih salah satu jawaban yang benar dari empat pilihan jawaban. Kemudian peneliti menanyakan kepada partisipan untuk memberikan donasi kepada panti asuhan atau tidak. Peneliti juga menanyakan nominal yang akan diberikan oleh partisipan. Apabila partisipan hanya menolong panti asuhan Raudhattul Jannah (Kelompok Agama Islam atau ingroup) dibandingkan panti asuhan Kasih Kudus (Kelompok Agama non-Islam) pada skenario penelitian.

Pada akhir penelitian, partisipan ditunjukkan video yang berjudul "Bhineka Tunggal Ika” yang berisi tentang keberagaman dan persatuan untuk menetralkan keadaan psikologis partisipan. Video tersebut menjelaskan tentang pentingnya setiap masyarakat Indonesia tidak membeda-bedakan orang lain berdasarkan latar belakang suku, agama, dan ras agar persatuan dan kesatuan Indonesia tetap terjaga. Setelah menonton video, partisipan memasuki sesi debriefing. Peneliti memberitahu tujuan penelitian sebenarnya, membagikan hadiah sebagai reward partisipasi penelitian dan mengucapkan terima kasih atas partisipasi penelitian.

\section{Instrumen Penelitian}

Skenario menolong atau tidak menolong terhadap kelompok. Peneliti membuat skenario untuk mengukur variabel terikat yaitu, intensi bias individu terhadap kelompok agama lain. Skenario tersebut menceritakan tentang partisipan yang diminta melihat remaja dengan membawa kotak donasi panti asuhan. Peneliti membedakan asal panti asuhan yaitu, panti asuhan bernama Kasih Kudus yang merepresentasikan panti asuhan kelompok Agama Kristen dan panti asuhan Radhatul Jannah yang merepresentasikan panti asuhan kelompok Agama Islam. Donasi yang diberikan kepada kedua panti asuhan akan digunakan untuk keperluan pendidikan anak panti asuhan. Partisipan diberi pertanyaan, "pada situasi tersebut, apakah Anda akan memberikan donasi?" Selain itu partisipan juga dimintai untuk memberikan jumlah donasi yang akan diberikan dalam jumlah uang. Landasan peneliti menggunakan donasi sebagai metode pengukuran bias dalam kelompok berasal studi De Freitas dan Cikara (2018). Dalam penelitian De Freitas dan Cikara (2018) bias dalam kelompok dilihat berdasarkan respon individu pemberian donasi kepada ingroup dan outgroup. Sama halnya dengan studi De Freitas dan Cikara (2018), penilaian bias dalam kelompok ditentukan berdasarkan kesediaan menolong berdasarkan kelompok target.

Dalam pertanyaan untuk menentukan jumlah donasi yang akan diberikan, peneliti memberikan pilihan dari nominal 0-100.000 rupiah. Manipulation check diberikan dengan memberikan tiga pertanyaan terkait jalannya cerita. Partisipan akan menjawab pertanyaan dari kedua versi skenario cover story secara bergantian (pertama menjawab skenario panti asuhan Kasih Kudus dan kemudian menjawab skenario panti asuhan Radhatul Jannah). Apabila partisipan hanya menolong panti asuhan Raudhattul Jannah (Kelompok Agama Islam) dibandingkan panti asuhan Kasih Kudus (Kelompok Agama non-Islam) pada skenario penelitian.

Instrumen manipulasi sudut pandang ketuhanan. Peneliti menggunakan penggalan Ayat suci Al Quran yang membahas tentang berperilaku adil terhadap sesama manusia sebagai manipulasi sudut pandang Ketuhanan. Ayat Suci berupa surat Al-Maidah ayat 8 yang menjelaskan bahwa setiap umat Islam hendak berperilaku adil terhadap semua manusia. Arti Ayat Suci Al Quran tersebut akan diperlihatkan kepada partisipan. Untuk manipulation check, kelompok sudut pandang Tuhan akan diminta me-rating pernyataan terkait pemahaman konsep Tuhan yang adil terhadap sesama manusia. Peneliti memberikan pernyataan "Tuhan memberikan kasih sayangnya pada seluruh umat manusia" dan "Saya percaya Tuhan memerintahkan sesama manusia untuk berlaku adil". Partisipan akan menjawab dengan merating sangat tidak setuju (1) sampai dengan sangat setuju (7). Partisipan akan menjawab dengan merating sangat tidak setuju (1) sampai dengan sangat setuju (7). Tingginya rating partisipan pada kedua pernyataan tersebut, maka manipulasi dapat disimpulkan berhasil dipahami oleh partisipan.

Uji coba penelitian. Peneliti melakukan pengujian kepada partisipan dengan rentang usia remaja akhir hingga dewasa muda, yaitu 18 sampai 27 tahun.

Uji coba skenario menolong atau tidak menolong terhadap kelompok. Dalam skenario, peneliti memberikan nama panti asuhan dengan nama yang dapat diidentifikasi berasal dari kelompok agama tertentu (Islam dan non-Islam). Sama seperti sebelumnya, peneliti juga membuat dua versi skenario, yaitu skenario versi pertama (skenario dengan target panti asuhan umat Kristen bernama "Kasih Kudus") dan versi kedua (skenario dengan target panti asuhan umat Islam bernama "Radhatul Jannah"). Dari 15 partisipan, terdapat partisipan yang memberikan sumbangan kepada kedua panti asuhan tanpa memperhatikan afiliasi keagamaan tanpa memperhatikan identitas kelompok agama (9 orang). Akan tetapi terdapat dua orang partisipan yang memberi sumbangan kepada salah satu panti asuhan saja dengan alasan afiliasi agama yang sama. Kemudian terdapat empat orang partisipan yang tidak ingin menyumbang kepada kedua panti asuhan, dengan alasan hanya ingin menyumbang melalui badan yang telah tersertifikasi 
secara hukum. Hasil ini menunjukkan bahwa skenario yang diberikan dapat memunculkan variasi respon bias berdasarkan kelompok target.

Uji coba manipulasi sudut pandang ketuhanan. Peneliti juga melakukan uji coba manipulasi sudut pandang Ketuhanan berupa terjemahan ayat suci Al Quran (Al-Maidah ayat 8). Pengujian dilakukan kepada delapan orang partisipan. Pada pengujian ini, partisipan diperlihatkan terjemahan ayat suci Al Quran (Al-Maidah ayat 8). Selanjutnya partisipan diminta untuk menjawab pertanyaan tentang apa yang diperintahkan Tuhan dalam ayat tersebut. Diperoleh kesimpulan bahwa partisipan dapat memahami maksud perintah Tuhan dalam ayat tersebut yang memerintahkan umatnya berlaku adil kepada seluruh umat manusia tanpa membedakan agamanya.

\section{Teknik Analisis}

Peneliti menggunakan teknik chi-square dalam menganalisis hasil penelitian. Teknik chi-square digunakan ketika kedua variabel penelitian baik variabel independen dan dependen memiliki data nominal. Berdasarkan perhitungan chi-square akan menghasilkan dua tabel yaitu tabel crosstabulation dan chi-square test (Field, 2009).

\section{Hasil Penelitian}

Peneliti menyimpulkan hasil manipulation check telah berhasil. Peneliti menyimpulkan hal ini berdasarkan respon partisipan yang menjawab "sangat setuju" pada dua pertanyaan yang disediakan oleh peneliti, yaitu menyetujui bahwa Tuhan menginginkan mereka untuk berlaku adil dan menyayangi seluruh umat manusia.

\section{Analisis Efek Manipulasi terhadap Bias}

Kemudian untuk analisis hasil, Tabel crosstabulation menjelaskan bahwa 37 (45,67\%) partisipan yang menggunakan sudut pandang dirinya tidak memiliki pemikiran bias dalam kelompok. Kemudian sebanyak $3(3,7 \%)$ orang partisipan yang menggunakan sudut pandang dirinya memiliki pemikiran bias dalam kelompok. Kemudian, sebanyak $39(48,14 \%)$ orang partisipan yang menggunakan sudut pandang Ketuhanan tidak memiliki pemikiran bias dalam kelompok. Sebanyak 2 (2,46\%) orang partisipan yang menggunakan sudut pandang Ketuhanan memiliki pemikiran bias dalam kelompok. Tabel berikut adalah penjelasan lebih detail tentang perhitungan crosstabulation.

Analisis chi-square menjelaskan bahwa $\chi 2$ (2) = $0,240, p>0,05, \eta=0,05$. Peneliti menyimpulkan bahwa hasil chi square $\chi 2$ menerima $\mathrm{H}_{0}$. Artinya, tidak terdapat perbedaan frekuensi dari pemikiran bias dalam kelompok pada kedua kelompok partisipan yang menggunakan sudut pandang dirinya maupun sudut pandang Ketuhanan. Dalam hal ini, hasil penelitian tidak dapat menerima hipotesis penelitian (Ho diterima).

Tabel 1. Tabel Crosstabulation untuk melihat pengaruh sudut pandang terhadap pemikiran bias dalam kelompok

\begin{tabular}{lccc}
\hline \multirow{2}{*}{ Sudut Pandang } & \multicolumn{2}{c}{ Bias dalam Kelompok } & \multirow{2}{*}{ Total } \\
\hline Diri & 37 & 3 & 40 \\
Ketuhanan & 39 & 2 & 41 \\
Total & 76 & 5 & 81 \\
\hline
\end{tabular}

Tabel 2. Tabel untuk signifikansi analisis Chi-square

\begin{tabular}{lcc}
\hline & Value & Asymp.Sig \\
\hline $\begin{array}{l}\text { Pearson Chi- } \\
\text { Square }\end{array}$ & 0,409 & 0,624 \\
\hline
\end{tabular}

\section{Analisis Efek Manipulasi terhadap Pemberian Donasi.}

Selanjutnya peneliti melakukan analisis dengan melihat perbedaan pemberian nominal donasi kepada panti asuhan (dalam skenario) oleh partisipan berdasarkan sudut pandang. Data pemberian donasi didapatkan melalui partisipan yang diminta untuk memberikan nominal donasi kepada kedua panti asuhan. Peneliti memberikan empat pilihan, yaitu "020.000", “21.000-40.000", “41.000-60.000", “61.00080.000 ", dan "81.000-100.000". Jawaban partisipan tersebut diubah menjadi sebuah skor, dan menghitung nilai rata-rata dari setiap kelompok partisipan. Berikut adalah perbandingan nilai rata-rata setiap kelompok partisipan. Target donasi ingroup adalah panti donasi yang diberikan kepada panti asuhan Islam, sedangkan target donasi outgroup adalah donasi untuk panti asuhan non-Islam.

Hasil analisis nominal pemberian donasi kepada panti asuhan outgroup (panti asuhan nonIslam) memperlihatkan $\mathrm{t}=-0,615, \mathrm{p}>0,05, \mathrm{~d}=0,13$. Artinya, tidak terdapat perbedaan nilai rata-rata dari pemberian donasi pada kedua kelompok partisipan berdasarkan sudut pandang. Meskipun tidak signifikan, penulis menyimpulkan bahwa kelompok partisipan sudut pandang Ketuhanan, memiliki nilai rata-rata pemberian nominal donasi kepada panti asuhan outgroup (panti asuhan non-Islam) yang lebih tinggi (sebesar 1,39) dibandingkan kelompok partisipan yang menggunakan sudut pandang diri (sebesar 1,25). 
Tabel 3. Tabel untuk signifikansi analisis perbandingan nilai rata-rata nominal pemberian donasi kepada panti asuhan

\begin{tabular}{lcccc}
\hline & \multicolumn{3}{c}{ Koefesien Uji t } \\
\hline Variabel Penelitian & 1 & 2 & 3 & 4 \\
\hline Sudut Pandang diri dan Ketuhanan (Variabel Independen) & 1 & & & \\
Keikutsertaan Organisasi (Variabel Indpenden) & 0,133 & 1 & & \\
Bias Kelompok dalam nominal pemberian donasi outgroup & $-0,615$ & - & 1 & 1 \\
Bias Kelompok dalam nominal pemberian donasi ingroup & $-0,688$ & $2,033^{*}$ & - & \\
\hline
\end{tabular}

Keterangan: *signifikan pada $\mathrm{p}<0,05$

Sedangkan untuk pemberian donasi kepada panti asuhan ingroup (panti asuhan Islam), kelompok partisipan sudut pandang Ketuhanan memiliki nilai rata-rata lebih tinggi (Sebesar 1,63) dibandingkan kelompok partisipan sudut pandang diri (sebesar 1,83) namun tidak terbukti signifikan $(t$ $=-0,688, p>0,05, d=0,14$ ).

Selanjutnya peneliti melakukan analisis untuk membandingkan nilai rata-rata pemberian donasi kepada panti asuhan berdasarkan keikutsertaan partisipan pada organisasi keagamaan (Islam). Hasil analisis nominal pemberian kepada panti asuhan outgroup (panti asuhan non-Islam) berdasarkan keikutsertaan organisasi keagamaan memperlihatkan $t=-0,281, p>0,05, d=0,06$. Artinya, tidak terdapat perbedaan secara signifikan, nilai rata-rata dari pemberian donasi pada kedua kelompok partisipan berdasarkan keikutsertaan organisasi keagamaan. Meskipun tidak signifikan, penulis menyimpulkan bahwa kelompok partisipan yang tidak mengikuti organisasi keagamaan, memiliki nilai rata-rata pemberian nominal donasi kepada panti asuhan outgroup (panti asuhan non-Islam) yang lebih tinggi (sebesar 1,35) dibandingkan kelompok partisipan yang mengikuti organsiasi keagamaan (sebesar 1,28).

Sedangkan untuk pemberian donasi kepada panti asuhan ingroup (panti asuhan Islam), terdapat perbedaan secara signifikan, nilai rata-rata dari pemberian donasi pada kedua kelompok partisipan berdasarkan keikutsertaan organisasi keagamaan. Lebih lanjut. kelompok partisipan yang mengikuti organisasi keagamaan atau organisasi Islam, memiliki nilai rata-rata lebih tinggi (sebesar 2,09) dibandingkan kelompok partisipan yang tidak mengikuti organisasi Islam dengan nilai rata-rata sebesar 1,49 $(t=2,033, p<0,05, d=0,45)$.

\section{Diskusi}

Berdasarkan hasil penelitian dapat disimpulkan bahwa tidak terdapat perbedaan yang signifikan, antara kelompok partisipan yang mengaktifkan sudut pandang dirinya dengan kelompok partisipan yang mengaktifkan sudut pandang Ketuhanan, dalam melakukan pemikiran bias dalam kelompok. Kedua kelompok partisipan tetap memutuskan untuk memberikan donasi untuk panti asuhan dari kelompok umat agama lain (umat non-Islam) dan kelompok umat agama seiman (Islam). Kemudian, secara signifikan, partisipan yang aktif mengikuti organisasi keagamaan (Islam) cenderung lebih banyak memberikan donasi kepada panti asuhan kelompok agama Islam (ingroup) dibandingkan partisipan yang tidak aktif dalam berorganisasi. Hasil penelitian ini sangat berbeda dengan penelitian yang dilakukan oleh Ginges dkk. (2016).

Hal ini dapat diatribusikan melalui beberapa eksplanasi. Misalnya berdasarkan studi dari Rutland, Cameron, Milne, dan McGeorge (2009) yang menjelaskan bahwa terdapat peran norma sosial dapat menurunkan bias dalam kelompok. Namun, bias kelompok tetap terjadi meskipun secara implisit pada individu. Akan tetapi, peneliti melihat perbedaan konteks wilayah konflik dan non-konflik yang mendasari perbedaan hasil penelitian tersebut. Perbedaan konteks lingkungan dapat berkontribusi dalam melihat pemikiran bias kelompok agama terhadap kelompok agama lain (Galen, 2012). Landasan berpikir ini berasal dari penelitian Kanas, Scheepers, dan Sterkens (2017). Penelitian tersebut melihat bahwa dalam wilayah konflik, individu lebih memiliki kontak dan penilaian negatif terhadap kelompok agama lain dibandingkan dengan individu pada wilayah non-konflik.

Selain itu, penelitian oleh Kanas dkk. (2015) juga membandingkan dua daerah yang saat itu masih berkonflik, yaitu Maluku dan non-konflik Yogyakarta. Peneltitian Kanas dkk. (2015) menjelaskan bahwa bias penilaian terhadap kelompok agama outgroup lebih banyak dilakukan di daerah Ambon, dimana memiliki sejarah konflik kelompok agama dibandingkan Yogyakarta. Hal yang memungkinkan dapat dijelaskan bahwa pada wilayah konflik, individu akan merasakan persepsi keterancaman atau bahkan mengancam kelangsungan hidup dari kelompok lain (outgroup) dibandingkan wilayah yang tidak dalam keadaan konflik (Stephan, Ybarra, \& Morrison, 2009). Penelitian dari Ginges dkk. (2016) dilakukan pada konteks wilayah yang sedang berkonflik yaitu Palestina dan Israel. Konteks konflik pada kedua negara tersebut sudah terjadi sangat lama bahkan hingga menimbulkan peperangan.

Lain halnya dengan Indonesia. Meskipun fenomena polarisasi dan bias kelompok agama terjadi, 
namun konflik antar kelompok agama tidak sama dengan konflik antara Palestina dan Israel. Di Indonesia memang terjadi beberapa konflik kelompok agama (Kanas dkk, 2015), namun tidak terjadi di semua daerah dan tidak sampai menimbulkan peperangan dan pertumpahan darah. Selain itu, mayoritas populasi masyarakat Indonesia (95 persen) menganggap nilai agama memegang peranan besar bagi perilaku masyarakat berdasarkan survei yang dilakukan Pengurus Besar Nahdlatul Ulama (PBNU) bersama Alava Research Center (Akbar, 2017). Peneliti menilai perbedaan konteks inilah yang mempengaruhi perbedaan hasil penelitian ini.

Hasil penelitian ini juga memperlihatkan perbedaan nominal donasi yang diberikan kepada panti asuhan Islam (dalam skenario). Partisipan yang mengikuti organisasi keagamaan memiliki nilai ratarata yang lebih tinggi dibandingkan partisipan yang tidak mengikuti organisasi keagamaan, dalam memberikan donasi kepada panti asuhan Islam. Meskipun tidak tergolong dalam pemikiran bias dalam kelompok, peneliti dapat menyimpulkan bahwa partisipan yang mengikuti organisasi keagamaan, lebih berintensi untuk menyumbangkan uang dengan nominal besar untuk panti asuhan atau lembaga yang berhubungan dengan kelompok umat agamanya dibandingkan umat agama lain. Hal ini sesuai dengan pembahasan dari Pichon dan Saroglou (2009) bahwa individu dengan religiositas yang tinggi memiliki kecenderungan untuk menolong individu lain, yang dikategorisasikan berasal dari kelompok (ingroup) dan tidak berintensi menolong individu dari kelompok lain (outgroup) khususnya yang dipersepsikan memiliki nilai berlawanan dengan agamanya.

Lebih lanjut, Malka, Lelkes, Srivastava, Cohen, dan Miller (2012) juga menyatakan keikutsertaan sebagai seorang aktivis dari organisasi keagamaan dapat menciptakan pemikiran konservatif pada individu. Artinya individu yang menjadi aktivis dari organisasi agama, memunculkan persepsi untuk tidak menerima perubahan dan hanya mempertahankan nilai-nilai keagamaan yang diajarkan dalam organisasi agama, misalnya bahwa menolong sesama umat Islam menjadi lebih diutamakan karena merupakan saudara seiman. Preston dan Ritter menjelaskan keikutsertaan individu dalam organisasi Islam tergolong dalam konsep religion. Individu yang memiliki konsep religion akan cenderung berperilaku sesuai dengan norma kelompoknya dan memiliki penilaian positif terhadap kelompok agamanya dibandingkan kelompok agama lain (Preston \& Ritter, 2013). Hal ini yang menjadi penjelasan penulis bahwa individu yang ikut serta dalam organisasi keagamaan akan lebih memberikan donasi kepada panti asuhan dari kelompok agamanya.

\section{Kesimpulan}

Penelitian ini bertujuan untuk melihat pengaruh perbedaan variasi sudut pandang diri dan Ketuhanan terhadap pemikiran bias dalam kelompok agama. Hasil penelitian ini menujukkan bahwa tidak terdapat perbedaan antara kelompok partisipan yang mengaktifkan sudut pandang Ketuhanan dan sudut pandang diri terhadap pemikiran bias dalam kelompok agama.

Terdapat beberapa keterbatasan dalam penelitian ini. Pertama, penggunaan manipulasi sudut pandang Ketuhanan mungkin memunculkan social desirability. Penelitian selanjutnya agar memperhatikan pengukuran social desirability pada partisipan. Keterbatasan pada hal metode lainnya yaitu, jumlah partisipan yang seharusnya masih dapat diperbanyak untuk memperkaya data penelitian. Lalu, adanya pelaksanaan penelitian eksperimen yang seharusnya dilakukan secara bersama-sama pada partisipan. Kemudian, penelitian berikutnya seharusnya dapat mengontrol kemungkinan confounding variable, misalnya peran kepatuhan norma sosial yang dapat muncul pada individu.

Limitasi berikutnya adalah kemungkinan adanya variabel lain yang dapat menjelaskan bentuk pengaruh sudut pandang Ketuhanan dan Diri terhadap pemikiran bias dalam kelompok agama. Pada penelitian ini, peneliti hanya melihat pengaruh kedua variasi sudut pandang diri dan Ketuhanan terhadap pemikiran bias dalam kelompok agama. Akan tetapi hasil penelitian ini belum cukup untuk menjelaskan adanya pengaruh kedua variabel tersebut. Hal ini memungkinkan penelitian selanjutnya dilakukan pada kelompok partisipan yang memiliki karakteristik khusus, seperti misalnya memiliki jadwal kegiatan pengajian rutin, atau melihat individu yang aktif dalam kelompok agama.

\section{Daftar Pustaka}

Akbar, C. (2017, 1 Februari). Survei: agama penting bagi kehidupan masyarakat indonesia. Diakses dari https://m.hidayatullah.com/berita/nasional/re ad/2017/02/01/110840/survei-agamapenting-bagi-kehidupan-masyarakatindonesia.html

De Freitas, J., \& Cikara, M. (2018). Deep down my enemy is good: Thinking about the true self reduces intergroup bias. Journal of Experimental Social Psychology, 74, 307-316. doi: 10.31234/osf.io/4gz35

Field, A. (2009). Discovering Statistics Using SPSS $\left(3^{\text {th }}\right.$ ed.). British: SAGE Publications.

Galen, L. W. (2012). Does religious belief promote prosociality? A critical examination. Psychological Bulletin, 138(5), 876-906. doi:10.1037/a0028251

Ginges, J., Hansen, I., Norenzayan, A. (2009). Religion and support for suicide attacks. Psychological Science. 20(2), 224-230. doi: 10.1111/j.14679280.2009.02270.x

Ginges, J., Sheikh, H., Atran. S., \& Argo, N. (2016) Thinking from god's perspective decreases 
biased valuation of the life if a nonbeliever. Psychological and Cognitive Science, 113(2), 316-319. doi: 10.1073/pnas.1512120113//DCSupplemental

Johnson, M. K., Rowatt, M. C., \& LaBouff, J. (2010). Priming christian religious concepts increases racial prejudice. Social Psychology and Personality Science, 1(2), 119-126. doi: $10.1177 / 1948550609357246$

Kanas, A., Scheepers, P., \& Sterkens, C. (2015). Interreligious contact, percieved group threat, and percieved discrimination: predicting negative attitudes among regligious minorities and majorities in indonesia. Social Psychology Qarterly, 78(2), 102-126. doi: $10.1177 / 0190272514564790$

Kanas, A., Scheepers, P., Sterkens, C. (2017). Positive and negative contact and attitudes towards the religious out-group: Testing the contact hypothesis in conflict and non-conflict regions of Indonesia and the Philippines. Social Science Research, $30 . \quad 1-16 . \quad$ doi: http://dx.doi.org/10.1016/j.ssresearch.2016.0 9.019

Katz, I., \&. Hass, R. G. (1988). Racial ambivalence and american value conflict: correlational and priming studies of dual cognitive structures. Journal of Personality and Social Psychology, 55(6), 893-905. doi: 10.1037//00223514.55.6.893

LaBouff, J. P., Rowatt, Johnson, M. K., \& Finkle, C. (2012). Differences in attitudes toward outgroups in religious and nonreligious contexts in a multinational sample: a situational context priming study. The International Journal for the Psychology of Religion, 22, 1-9. doi: 10.1080/10508619.2012.634778

Malka, A., Lelkes, Y., Srivastava, S., Cohen, A. B., \& Miller, D. T. (2012). The association of religiousity and polotical conservatism: the role of political engagement. Political Psychology,
33(2). 275-299. doi: 10.1111/j.14679221.2012.00875.x

Pichon, I., \& Saroglou, V. (2009). Religion and helping impact of target thinking styles and just-world beliefs. Archive for the Psychology of Religion, 31, 215-236. doi: 10.1163/157361209x424466

Preston, J. L., Ritter, R. S., \& Hernandez, J. I. (2010). Principles of religious prosociality: a review and reformulation. Social and Personality Psychology Compass, 4(8), 574-590.10.1111/j.17519004.2010.00286.x. doi: 10.1111/j.17519004.2010.00286.x

Preston, J. L., \& Ritter, R. S. (2013). Different effects of religion and god on prosociality with ingroup and outgroup. Personality and Social Psychology Bulletin, 39(11), 1471-1483. doi: 10.1177/0146167213499937

Rutland, A., Cameron, L., Milne, A., \& McGeorge, P. (2005). Social norms and self-presentation: Children's implicit and explicit intergroup attitudes. Child development, 76(2), 451-466. doi: 10.1111/j.1467-8624.2005.00856.x

Seniati, L., Yulianto, A., \& Setiadi, B. N. (2011). Psikologi Eksperimen. Jakarta: Indeks.

Stefanie, C. (2017, 17 Juli). Menteri PPPA: Siswa Ditolak Sekolah karena Diskriminasi Agama. Diakses dari https://www.cnnindonesia.com/nasional/201 70717164312-20-228414/menteri-pppasiswa-ditolak-sekolah-karena-diskriminasiagama

Stephan, W. G., Ybarra, O., \& Morrison, K. R. (2009). Intergroup threat theory. In T. D. Nelson (Ed.), Handbook of prejudice, stereotyping, and discrimination (pp. 43-59). New York, NY, US: Psychology Press.

Tajfel, H. (1970). Experiments in intergroup discrimination. Scientific American, 223(5), 96102. doi:10.1038/scientificamerican1170-96

Tajfel, H., Turner, J. C., Austin, W. G., \& Worchel, S. (1979). An integrative theory of intergroup conflict. Organizational identity: A reader, 56-65. 